\title{
Modeling water requirements of major crops and their responses to climate change in the North China Plain
}

\author{
Xinping $\mathrm{Luo}^{2} \cdot$ Jun $\mathrm{Xia}^{1,2} \cdot$ Hong $\mathrm{Yang}^{3}$
}

Received: 12 September 2014/Accepted: 5 April 2015/Published online: 19 April 2015

(C) Springer-Verlag Berlin Heidelberg 2015

\begin{abstract}
The North China Plain (NCP) is one of the most important food production bases in China. However, its agriculture water resources are threatened by climate change. In this paper, the CROPWAT model is used to evaluate crop water requirement (CWR), crop green water requirement (CGWR), and crop blue water requirement (CBWR) for main crops in NCP (winter wheat, summer maize, cotton, millet, and soybean) with a spatial resolution of 5 arc-minute from 1961 to 2010 . Their responses to future climate changes are investigated. The results show that the mean annual total CWR of the main crops during growing periods amounted to $114.68 \mathrm{~km}^{3} \mathrm{a}^{-1}$ in the past 50 years. More than $72 \%$ of CWR to support NCP crop production is green water. The spatial distributions of CWR, CGWR, and CBWR are closely related to the planting areas and irrigation availability. Summer maize, millet, and soybean are high CGWR crops with proportions of above $84 \%$, while the lowest CGWR proportion is in winter wheat, $58.89 \%$. For climate change impacts in future, holding the crop planting system and irrigation conditions unchanged, it is projected
\end{abstract}

Jun Xia

luoxp@igsnrr.ac.cn

Xinping Luo

LXP_830520@163.com

1 State Key Laboratory of Water Resources and Hydropower Engineering Science, Wuhan University, Wuhan, People's Republic of China

2 Key Laboratory of Water Cycle and Related Land Surface Processes, Institute of Geographic Sciences and Natural Resources Research, Chinese Academy of Sciences, Beijing 100101, People's Republic of China

3 Swiss Federal Institute of Aquatic Science and Technology (Eawag), Ueberlandstrasse133, P.O. Box 611, 8600 Duebendorf, Switzerland that the total CWR in 2030s will require approximately $8.75-11.25 \mathrm{~km}^{3} \mathrm{a}^{-1}$ additional water. Results show that the CWR increase in 2030s is mainly due to the increase in temperature. Under the projected temperature in 2030s and the current rainfall scenario, total CWR, CGWR, and CBWR increments were $8.58,1.76$, and $6.82 \mathrm{~km}^{3} \mathrm{a}^{-1}$, respectively. Nearly $80 \%$ of the CWR increment is from the increase in CBWR. Therefore, agricultural water shortage crisis will further aggravate under future climate change scenarios in $\mathrm{NCP}$, and effective water-saving measures must be taken to mitigate the negative effects of climate change.

Keywords Crop water requirement - Climate change . CROPWAT - The North China Plain · Water security

\section{Introduction}

Climate change and its impacts on food production and agricultural water management are major challenges which China will have to cope with in the twenty-first century (Piao et al. 2010). According to the Fifth Assessment Report of the Intergovernmental Panel on Climate Change (IPCC), the global average surface temperature has increased $0.65-1.06{ }^{\circ} \mathrm{C}$ in the past 130 years $(1880-2012)$ (IPCC 2013; Qin et al. 2014). Climate change not only affects the spatial and temporal distribution of water resources, but also will increase the crop evapotranspiration, heightening the instability and imbalance of the supply and demand of agriculture water resources (Oki and Kanae 2006; Piao et al. 2010). Therefore, understanding of adaptation to climate change is important for agricultural water security in the sustainable development of China.

One aspect of the climate change has been global warming. It may increase the potential evapotranspiration 
in the crop growing season which leads to decrease in the effectiveness of soil water, thereby increases the water requirement for irrigation. Crop water requirement (CWR) refers to the amount of water needed to compensate the evapotranspiration loss from the crop field during a specified period of time. The information is useful for management purposes in estimating irrigation water requirements, irrigation scheduling, and water delivery scheduling (Todorovic 2005). So far, there have been considerable research attempting to model the effects of climate change on global water resources and agriculture production (Thomson et al. 2006; Mimi and Jamous 2010; Zhou et al. 2012; Yao and Xu 2013; Samper et al. 2015; Antonellini et al. 2014; Prăvălie et al. 2014; Zinyengere et al. 2014; Thevs et al. 2015). However, food production not only consumes "blue water" which is withdrawn from water bodies and groundwater and used for irrigation, but also relies on "green water" (rainfed agriculture) (Falkenmark 2003; Liu and Savenije 2008). Accordingly, CWR can be partitioned into crop blue water requirements (CBWR) and crop green water requirements (CGWR). Recently, a much large amount of global green water and blue water assessments have been reported with different hydrological models (Rost et al. 2008; Hoff et al. 2010; Fader et al. 2011; Liu et al. 2009; Liu and Yang 2010; Zang et al. 2012; Zhang et al. 2014). In addition, many studies have investigated global change impacts on crop yield and consumptive blue and green water use by establishing different scenarios (Liu et al. 2013; Zang et al. 2013; Chen et al. 2014), but the impact of climate factors on CBWR and CGWR remains a rarely studied issue. For better management of agricultural water resources and food productions, it is important to understand CWR, CBWR, and CGWR at the current level and possible effects of climate change on them in the future.

The North China Plain (NCP) is known as the "breadbasket of China". It is an important food production base and plays a decisive role in guaranteeing nation grain safety. It accounts for $26 \%$ of the total grain production, although it has only $21 \%$ of the planting areas as well as $6.65 \%$ of the water resources of China (Shi 2008). As one of the sensitive areas of China, the water resources in NCP will be affected greatly under climate change, which can cause great impact on agricultural water use and food production for the region. Research showed that by 2030, climate change and increasing water demand will bring about increasing vulnerability to this region and aggravating the water shortage problems in the future (Xia et al. 2012). Several researchers have investigated the potential impacts of climate variability on crop water consumption and crop productivity in NCP with different agricultural system models. For example, Liu and Lin (2004) analyzed the impact of different temperatures on water requirement of the main crops in NCP. Results showed that climate change will have great impact on water requirement of winter wheat, followed by cotton and summer maize. Mo et al. (2005) evaluated the spatial variations of crop yield, water consumption, and water productivity (WP) with SVATcrop growth model and found that spatial patterns of these items are closely related to water management patterns. Using the Vegetation Interface Processes (VIP) model, Mo et al. (2009) evaluated crop yield, water consumption, and water use efficiency (WUE) of winter wheat and summer maize in NCP from 1951 to 2006, and their responses to future climate scenarios. Results showed a rapid enhancement of crop yield in the past 56 years, accompanying with a slight increment of ET and noticeable improvement of WUE. For the future climate, it is found that winter wheat yield will increase by $19 \%$ for A2 and $13 \%$ for B 1 scenarios, and summer maize yield will decline by $15 \%$ for A2 and $12 \%$ for B1 scenario, respectively. Based on the CERES-Wheat and Maize models, Guo et al. (2010) found that under the same scenarios, wheat yield ascended due to climatic warming, but the maize yield descended. And high temperature also has positive effect on water use efficiencies. Chen et al. (2010) investigated the response of crop productivity and water balance to climate variations and irrigation by using the APSIM model. Wang et al. (2013) analyzed the response of varietal and temperature changes on winter wheat in NCP. Results showed that the increase in temperature shortened the growth duration of winter wheat mainly by shortening the growth period from sowing to jointing. Xiao and Tao (2014) found that climate change contributed to wheat yield generally by $-3.0-3.0 \%$ from 1980 to 2009 , however by $-15.0 \%$ for rainfed wheat in southern part of the NCP. Although these studies provide useful information for the development of applicable water management practices, they have focused on overall water requirements. Blue water requirements and green water requirements for major crops produced in NCP have not been well reported. Further studies on possible effects of climate change on CWR, CGWR, and CBWR for major crops in NCP are also barely reported.

There are many crop models that have been used for investigating CWR and crop yields. CROPWAT is one of them. It was developed by Food and Agriculture Organization (FAO) (FAO 2009). CROPWAT has been widely used in assessing and predicting CWR, deficit irrigation scheduling, and cropping patterns in many countries of the world (George et al. 2000; Nazeer 2009; Wang and Feng 2012; Conrad et al. 2013; Chowdhury et al. 2013). The results of these studies indicated that the CROPWAT model is a reliable tool in understanding CWR, irrigation planning, and manage irrigation scheduling.

The objective of this study is to utilize climate datasets from 1961 to 2010 to investigate the water requirements of 
major crops (winter wheat, summer maize, cotton, millet, and soybean). It distinguishes the blue water requirements and green water requirements with a spatial resolution of 5 arc-minute by applying the CROPWAT model and understand the implications of climate change for CWR, CGWR, and CBWR in 2030s (from 2031 to 2040) over the NCP regions.

\section{Materials and methods}

\section{Study area}

$\mathrm{NCP}$ is one of the granaries in China, extending from $31^{\circ} 24^{\prime} \mathrm{N}$ to $42^{\circ} 42^{\prime} \mathrm{N}$ and $110^{\circ} 18^{\prime} \mathrm{E}$ to $122^{\circ} 42^{\prime} \mathrm{E}$ (Fig. 1). It is located in the eastern part of China with an area of $33 \times 10^{4} \mathrm{~km}^{2}$, covering entire Beijing and Tianjin municipalities, the majority of Heibei, Shandong, and Henan provinces, and the northern parts of Jiangsu and Anhui provinces, which is an alluvial plain developed by the intermittent flooding of the Huang (yellow), Huai, and Hai rivers. NCP is located in the downstream of the Yellow River and mainly consists of loamy textural soil (Mo et al. 2013). The region is dominated by semi-humid monsoon climate with significant seasonal changes. The mean annual temperature and long-term average annual precipitation are in the range of $8-15{ }^{\circ} \mathrm{C}$ and $500-950 \mathrm{~mm}$, respectively

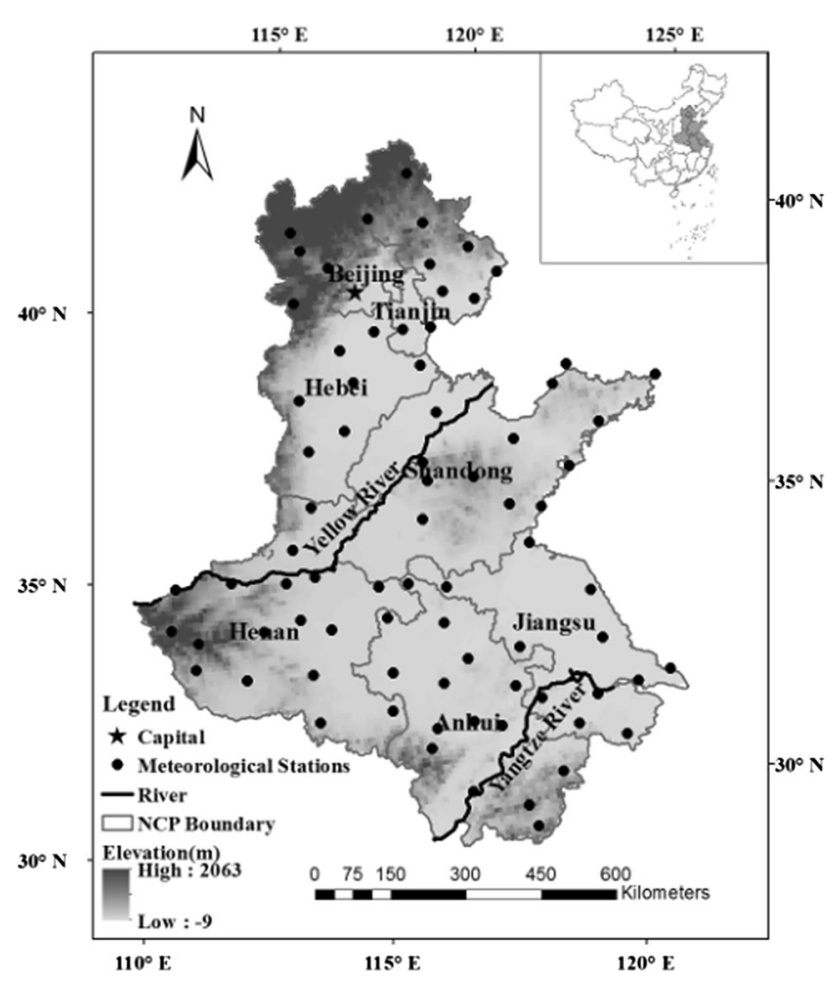

Fig. 1 Location map showing the NCP, China
(Zhao et al. 2013). More than $70 \%$ of the annual precipitation falls from July to September and decreases from northwest to southeast (Zhang et al. 1999; Fan et al. 2012). The NCP has experienced a significant decrease in sunshine hours and radiation since 1961 and increasing air temperature since the early 1980s (Ding et al. 2006; Li et al. 2014; Piao et al. 2010). Since the 1950s, the precipitation in the region has shown a decreasing trend which had a negative effect on agriculture water resources (Mo et al. 2009; Guo et al. 2010).

Due to its excellent thermal conditions and flat terrain, the NCP has become one of the most important agricultural regions in China. The major crops in NCP are wheat, maize, cotton, millet, and soybean. It is the major production area for wheat and maize. Double-cropping production system of winter wheat-summer maize had advantages in the plain; due to insufficient precipitation in the growing season and irregular distribution among seasons, the spring crops (such as wheat) usually need supplemental irrigation to obtain favorite production. Although NCP accounts for $14 \%$ of the total land area of China, it has only $7-8 \%$ of the water resources. The region has high irrigation coverage and the agricultural water demand is high. During the wheat growing season, rainfall ranges from 100 to $180 \mathrm{~mm}$ and can only meet $25-40 \%$ of crop water requirement. The water deficit in the winter wheat growing season (October to June) reaches up to 200-300 mm. Irrigation is the only source to maintain and enhance crop growth and yield, which cause a rapid decline in the groundwater table (Zhang et al. 1999; Iqbal et al. 2014). Climate variability still dominated the impact of the hydrological system changes in the upstream and downstream areas ( $\mathrm{Lu}$ et al. 2015). It is predicted that agricultural water use would be 31.2 billion $\mathrm{m}^{3}$ and agricultural water shortage will be 7.2 billion $\mathrm{m}^{3}$ of NCP in 2030 (Zhang et al. 2011). Water shortage has become the main restricted factors in the further development of the region and badly restricted the agricultural development.

\section{Data collection}

The data used in this study can be classified into three groups:

Meteorological data. In order to calculate the reference evapotranspiration $\left(\mathrm{ET}_{0}\right)$, the respective climatic data should be collected from the nearest and most representative meteorological stations. In our studies, the climatic data for the NCP have been obtained from China Meteorological Data Sharing Service system which included the standard meteorological observations about 77 meteorological stations. And the stations were spatially well distributed over the study area (Fig. 1). The dataset available from these stations included a time series starting on 1 
January 1961 up to 31 December 2010 for the following parameters: rainfall, minimum and maximum temperature, humidity, wind speed, sunshine hours. Simulations were done using the mean value of each parameter. These data were used to predict CWR for the current climatic conditions. To predict CWR for future climatic conditions, the World Climate Research Programme's (WCRP's) Coupled Model Intercomparison Project phase 5 (CMIP5) multimodel dataset provided by the National Climate Center were used. The Regional Integrated Model system-Regional Model Program (RMP) is forced by the representative concentration pathways (RCP) 4.5 and 8.5 scenarios from IPCC fifth assessment report (AR5).They are labeled according to the approximate values of the global radiative forcing in 2100 (Moss et al. 2010).

Crop data. Crop data variables on different grain crops such as cropping pattern, planting, and harvesting dates in NCP were obtained from household field survey and from the Provincial Offices of the Ministry of Agriculture. The planting area of crops data were obtained from the Center for Sustainability and the Global Environment (SAGE) of the University of Wisconsin at Madison, USA (Monfreda et al. 2008). The SAGE dataset provides planting area of 175 primary crops in the year 2000 with spatial resolutions of $5 \mathrm{~min}$. And the harvested areas of irrigated crops are calculated mainly based on the SAGE planting area data and the global map of irrigated areas (Siebert et al. 2007). The details of the planting area and planting and harvesting dates of corresponding grain crops are presented in Table 1. The crop growth stage coefficient $\left(K_{\mathrm{c}}\right)$ was obtained from FAO database for each crop. The growing stages for different crops and values of $K_{\mathrm{c}}$ at different growing stages for various crops are shown in Table 2.

Soil and other data. The agricultural soil is mainly calcareous and alluvial soil in most NCP regions, but partly yellow and brown soil (Guo et al. 2010). Other data such as latitude, longitude, and altitude were incorporated into the model.

\section{Methods}

\section{Model description}

CROPWAT is a decision support system which can simulate crop water requirements and irrigation requirements for various crops and under different climatic conditions (FAO 2009). The reference evapotranspiration, crop water requirements, and irrigation requirements are estimated based on a daily soil moisture balance using various options for the water supply and irrigation management conditions (Stancalie et al. 2010).

To run the CROPWAT model, the program requires climatic parameters (e.g., maximum and minimum temperature, wind speed, sunshine, humidity, and rainfall), planting and harvesting dates of crops, soil type, and cultivation area of crops for estimating CWR. Given the required meteorology, crop and soil data, the CROPWAT model can be used to calculate CWR for each crop in decade of a month. The first step in the CROPWAT model is to predict $\mathrm{CWR}_{i}$ on a 10 day basis as

$\mathrm{CWR}_{i}=\mathrm{ET}_{0} \times K_{\mathrm{c}}$,

where $\mathrm{CWR}_{i}$ is the crop water requirement of crop $\mathrm{i}$ $(\mathrm{mm} / \mathrm{day}), \mathrm{ET}_{0}$ is the reference crop evapotranspiration (mm/day), and $K_{\mathrm{c}}$ is the crop coefficient at a specific growth stage. The parameter $K_{\mathrm{c}}$ depends on the type of crop (e.g., height of crop, resistance of canopy, albedo), soil and climatic parameters, such as soil surface, evapotation, and wind speed and direction (Allen et al. 1998). The Penman-Monteith explicit equation was used to determine $\mathrm{ET}_{0}$. The equation can be presented as

$\mathrm{ET}_{0}=\frac{0.408 \Delta\left(R_{n}-G\right)+\gamma \frac{900}{T+273} U_{2}\left(e_{\mathrm{s}}-e_{a}\right)}{\Delta+\gamma\left(1+0.34 U_{2}\right)}$,

where $E T_{O}$ is the reference crop evapotranspiration, $\mathrm{mm}$ $\mathrm{d}^{-1} ; R_{n}$ is the net radiation at crop surface, $\mathrm{MJ} \mathrm{m}^{-2} \mathrm{~d}^{-1}$; $G$ is the soil heat flux, MJ m ${ }^{-2} \mathrm{~d}^{-1} ; T$ is the average air temperature recorded at $2.0-\mathrm{m}$ height, ${ }^{\circ} \mathrm{C} ; U_{2}$ is wind speed measured at $2.0-\mathrm{m}$ height, $\mathrm{m} \mathrm{s}^{-1} ;\left(e_{s}-e_{a}\right)$ is the vapor pressure deficit, $\mathrm{kPa} ; \triangle$ is the slope vapor pressure curve, $\mathrm{kPa}^{\circ} \mathrm{C}^{-1} ; \gamma$ is the psychrometric constant, $\mathrm{kPa}{ }^{\circ} \mathrm{C}^{-1}$, and 900 is the conversion factor.

In assessing CWR for a crop, the second step is to know the effective rainfall over the planted area. CROPWAT provided four common empirical methods for calculating effective rainfall: (1) fixed percentage; (2) dependable rain; (3) empirical formula; (4) USDA soil conservation service. The USDA soil conservation service method was used in the study as follows:
Table 1 Planting Area, and planting and harvesting dates for different crops in NCP

\begin{tabular}{lccc}
\hline Crops & Planting area $\left(\mathrm{km}^{2}\right)$ & Planting date & Harvesting date \\
\hline Winter wheat & 146,729 & $25 / 09-05 / 10$ & $17 / 06-25 / 06$ \\
Summer maize & 85,333 & $06 / 06-15 / 06$ & $11 / 10-20 / 10$ \\
Cotton & 24,162 & $11 / 04-21 / 04$ & $05 / 09-15 / 09$ \\
Millet & 4817 & $01 / 06-10 / 06$ & $11 / 09-20 / 09$ \\
Soybean & 22,739 & $11 / 06-20 / 06$ & $01 / 10-10 / 10$ \\
\hline
\end{tabular}


Table 2 Growing stages and crop growth stage coefficient $\left(K_{c}\right)$

\begin{tabular}{|c|c|c|c|c|c|c|c|c|}
\hline \multirow[t]{2}{*}{ Crops } & \multicolumn{4}{|c|}{ Growing stages (days) } & \multirow[t]{2}{*}{ Total stage (days) } & \multicolumn{3}{|c|}{ Crop growth stage coefficient $\left(K_{c}\right)$} \\
\hline & Initial & Develop. & Mid-season & Late season & & Initial & Mid-season & Late season \\
\hline Winter wheat & 157 & 31 & 17 & 43 & 248 & 0.40 & 1.15 & 0.25 \\
\hline Summer maize & 20 & 35 & 24 & 48 & 127 & 0.30 & 1.20 & 0.50 \\
\hline Cotton & 8 & 52 & 20 & 63 & 143 & 0.35 & 1.20 & 0.60 \\
\hline Millet & 15 & 25 & 40 & 25 & 105 & 0.30 & 1.00 & 0.30 \\
\hline Soybean & 20 & 25 & 55 & 22 & 122 & 0.40 & 1.15 & 0.50 \\
\hline
\end{tabular}

$$
P_{\text {eff }}=P_{\text {tot }} \times \frac{125-0.2 P_{\text {tot }}}{125} \quad\left(\text { for } \mathrm{P}_{\text {tot }}<250 \mathrm{~mm}\right),
$$$$
\text { and } P_{\text {eff }}=125+0.1 \times P_{\text {tot }} \quad\left(\text { for } \mathrm{P}_{\text {tot }}>250 \mathrm{~mm}\right)
$$

where $P_{\text {eff }}$ is the effective rainfall $(\mathrm{mm})$ and $P_{\text {tot }}$ is the measured total rainfall $(\mathrm{mm})$.

\section{Calculation of CGWR and CBWR}

For rainfed crops, effective rainfall is the only source for soil water availability and CWR is all from green water. For irrigated crops, due to lack of irrigation schedule information, we assumed sufficient irrigation water to meet crop water requirement. Under the irrigation condition, CWR is partly from green water and partly from blue water. Following the prediction of $\mathrm{CWR}_{i}$ for each crop, the $\mathrm{CGWR}_{i}$ and $\mathrm{CBWR}_{i}$ in entire crop growth period can be predicted as

$\mathrm{CGWR}_{i}=\min \left(\mathrm{CWR}_{i}, P_{\text {eff }}\right)$

$\mathrm{CBWR}_{i}=\mathrm{CWR}_{i}-\mathrm{CGWR}_{i}$,

where $\mathrm{CWR}_{i}, \mathrm{CGWR}_{i}$, and $\mathrm{CBWR}_{i}$ are crop green water requirement and crop blue water requirement for each crop in one grid cell, respectively ( $\mathrm{mm} /$ day); the subscript $\mathrm{i}$ represents the crop code; $P_{\text {eff }}$ is the effective rainfall ( $\mathrm{mm} /$ day).

After simulating the $\mathrm{CGWR}_{i}$ and $\mathrm{CBWR}_{i}$ for each crop in one grid cell, the total CGWR and CBWR of all crops can be calculated based on the planting areas and irrigation proportion of different crops; kriging interpolation method was used to obtain the entire NCP regional $C W R$.

$$
\begin{aligned}
& \mathrm{CGWR}=10 \times \sum_{i=1}^{n}\left(\mathrm{CGWR}_{i} \times A_{i}\right) \\
& \mathrm{CBWR}=10 \times \sum_{i=1}^{n}\left(\mathrm{CBWR}_{i} \times A_{i} \times I_{i}\right),
\end{aligned}
$$

where CWR, CGWR, and CBWR are the total water requirements, green water requirements, and blue water requirements of all crops, respectively $\left(\mathrm{m}^{3} \mathrm{a}^{-1}\right)$; the subscript $i$ represents the crop code; $n$ is the total number of crops selected; $A$ is the planted area of crop $i$ (ha); $I_{i}$ is the proportion of irrigation area in land area of crop $i(\%)$; the number 10 is used to convert from $\mathrm{mm}$ to $\mathrm{m}^{3} \mathrm{ha}^{-1}$.

\section{Validation of the model}

The CROPWAT model is very sensitive to climatic and crop growth data. To run the CROPWAT model, we need to calibrate and validate the results with local measurements. This study used the observational data of winter wheat and summer maize and cotton to validate the estimated CWR by CROPWAT model. The measured data of typical sites were obtained from "A contour map book of main crops water requirement in China" (Chen and Guo 1993) and "Irrigation water quota of main crops in the northern areas" (Duan 2004).

Results in Table 3 shows that the comparison of estimated CWR of major crops with the observational data. The error ranges of winter wheat and summer maize and cotton were $-12.27-1.71 \%, \quad-11.02-29.46 \%$, and $-6.19-20.62 \%$, respectively. In the whole, the maximum relative errors of the three crops were found in Shijiazhuang station. In other observation stations, CWR relative errors were all around $10 \%$. The statistical analyses indicate that the CROPWAT model performs well in simulating CWR in the NCP regions.

\section{Results and discussion}

\section{Crop water requirements in current climatic conditions}

The spatial distribution of CWR, CGWR, and CBWR shows a trend that values in central regions were higher than that in north and south regions (Fig. 2). The higher CWR values are mainly distributed in the south of Hebei, Shandong, Henan, Jiangsu, and the north of Anhui province. The proportion of irrigated areas along the Yellow River was large, which leads to high CWR and CBWR in Hebei, Shandong, and Anhui provinces. It indicates that CWR is not only impacted by planting areas, but is also related to the irrigation availability. In the south of Heibei, 
Shandong, the middle of Henan, Jiangsu, and the north of Anhui regions, due to the high cropping index and crop planting density, most of the annual crop water demand per grid was more than 10 million $\mathrm{m}^{3}$.

As shown in Table 4, the simulation mean annual CWR of major crops in crop growing periods amounted to $114.68 \mathrm{~km}^{3} \mathrm{a}^{-1}$ from 1961 to 2010 . The highest CWR was found in Henan, Shandong, and Hebei provinces where the proportions were $27.23,26.51$, and $22.08 \%$, respectively. More than $72 \%$ of $C W R$ to support NCP crop production comprises green water. This is lower than the estimate of
$81 \%$ reported by Liu et al. (2009). Among these regions, Anhui and Jiangsu provinces both have high green water proportion, exceeding $92 \%$, indicating that the crops in these regions mainly rely on rainfall. Other $\mathrm{NCP}$ regions all have CGWR proportions of below $76 \%$, which indicate high reliance of these regions on irrigation.

For different crops in the NCP regions, the main water requirement crops were winter wheat and summer maize. The proportions of CWR in the total crops water demand were 49.51 and $29.19 \%$ respectively which account for four fifths of the total CWR of major crops (Fig. 3a). As
Table 3 Validation of the estimated typical sites CWR with measurements $\left(10^{5} \mathrm{~m}^{3}\right)$

\begin{tabular}{lrrrr}
\hline Station & Observational value & Estimated value & Absolute error & Relative error (\%) \\
\hline Winter wheat & & & & \\
Yanzhou & 173.04 & 152.87 & -20.17 & -11.66 \\
Bengbu & 98.68 & 100.37 & 1.69 & 1.71 \\
Shijiazhuang & 42.21 & 37.03 & -5.18 & -12.27 \\
Hefei & 43.86 & 43.37 & -0.49 & -1.12 \\
& & & & \\
Summer maize & & & & -11.02 \\
Anyang & 173.28 & 154.18 & -19.1 & 29.46 \\
Shijiazhuang & 25.90 & 33.53 & 7.63 & -8.17 \\
Nanyang & 26.20 & 24.06 & -2.14 & 12.14 \\
Weifang & 102.11 & 114.51 & 12.4 & \\
& & & & -3.00 \\
Cotton & & & -1.27 & 7.73 \\
Dongtai & 42.31 & 41.04 & 1.42 & 20.62 \\
Bengbu & 18.36 & 19.78 & 0.20 & -6.19 \\
Shijiazhuang & 0.97 & 1.17 & 1.43 & \\
Nanyang & 44.21 & 45.64 & -1.68 & \\
Hefei & 27.16 & 25.84 & & \\
\hline
\end{tabular}

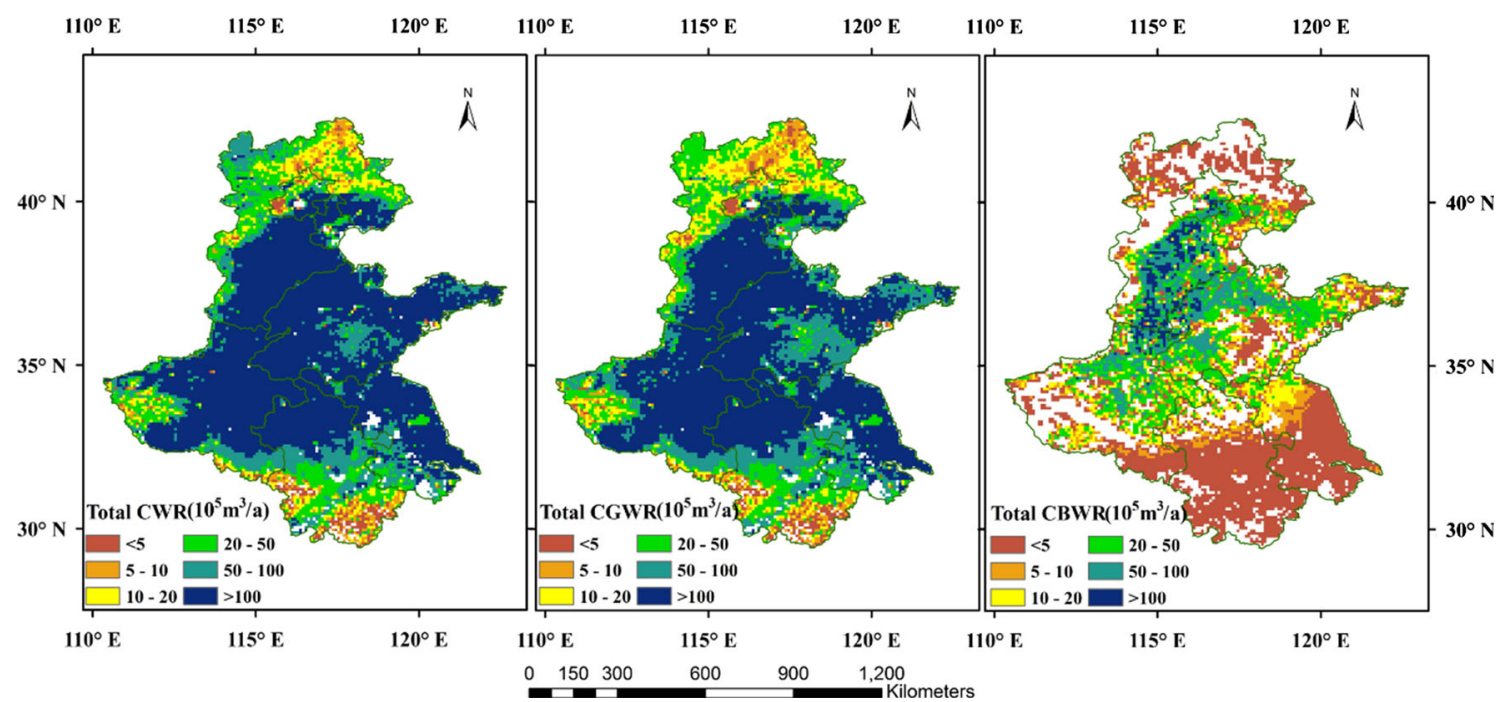

Fig. 2 Simulated CWR, CGWR, and CBWR for major crops (average of 1961-2010) 
Table 4 Provincial averages of crop water requirements in crop growing periods

\begin{tabular}{|c|c|c|c|c|c|}
\hline \multirow[t]{2}{*}{ Province } & \multicolumn{3}{|c|}{ Crop water requirements $\left(10^{8} \mathrm{~m}^{3} / \mathrm{a}\right)$} & \multirow{2}{*}{$\begin{array}{l}\text { CGWR/CWR } \\
(\%)\end{array}$} & \multirow{2}{*}{$\begin{array}{l}\text { The proportion of province } \\
\text { CWR in NCP }(\%)\end{array}$} \\
\hline & Total CWR & Total CGWR & Total CBWR & & \\
\hline Beijing & 16.56 & 9.02 & 7.54 & 54.45 & 1.44 \\
\hline Tianjin & 14.42 & 8.71 & 5.71 & 60.41 & 1.26 \\
\hline Hebei & 253.16 & 142.43 & 110.72 & 56.26 & 22.08 \\
\hline Shandong & 304.06 & 203.09 & 100.97 & 66.79 & 26.51 \\
\hline Henan & 312.21 & 235.23 & 76.98 & 75.34 & 27.23 \\
\hline Anhui & 124.29 & 116.40 & 7.89 & 93.65 & 10.84 \\
\hline Jiangsu & 122.08 & 113.18 & 8.91 & 92.70 & 10.65 \\
\hline NCP & 1146.78 & 828.07 & 318.72 & 72.21 & 100.00 \\
\hline
\end{tabular}

Fig. 3 Percentages of CWR, CGWR, and CBWR in NCP

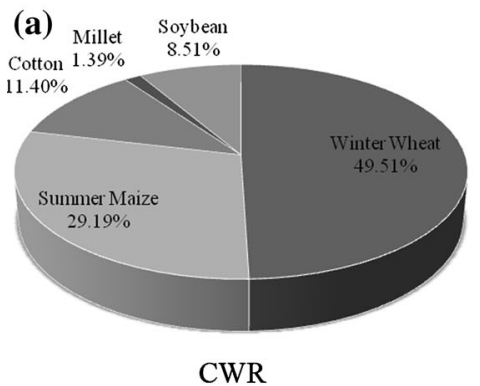

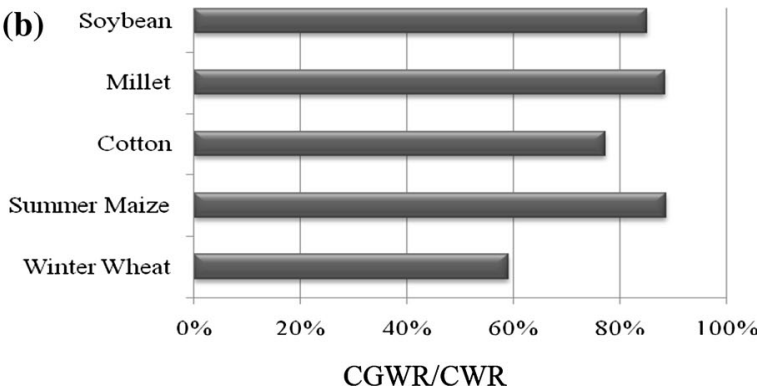

winter wheat in NCP is the largest CWR in terms of harvested area and production, the simulated $C W R$ values in different NCP regions were compared with those from Liu (2007) who estimated by GEPIC model (Table 5). In general, Liu (2007) provided a wheat water requirement value of $63.99 \mathrm{~km}^{3} \mathrm{a}^{-1}$ in NCP, which was more higher than our estimate of $56.78 \mathrm{~km}^{3} \mathrm{a}^{-1}$ in wheat growing periods. The results showed that the difference between wheat water requirement estimated by CROPWAT and GEPIC model was within the range of $37 \%$ in the 7 regions.

Figure $3 b$ shows the percentages of CGWR for five different crops in NCP. Among these crops, the percentages of summer maize, millet, and soybean were 88.42, 88.66 , and $84.78 \%$, respectively, which were higher than other crops. Winter wheat has the lowest green water proportion of $58.89 \%$ among all major crops. In the NCP regions, the rainfall is relatively abundant and ranging from 430 to $1390 \mathrm{~mm}$. However, $70 \%$ of the rainfall is concentrated in the period from July to September (Wang et al. 2001). During the winter wheat growing critical period (March to May), the rainfall in most regions is less than $80 \mathrm{~mm}$ which cannot meet the winter wheat water demand. The effective rainfall is far below the actual crop water consumption. Groundwater irrigation becomes an important practice to ensure high wheat yield. While the summer maize, millet, and soybean growing periods are generally during the rainfall seasons, natural rainfall can basically meet the crop growth need.

\section{Impact of climate change on crop water requirements}

To analyze the impact of climate change on CWR of different crops in the NCP regions, two scenarios are investigated as follows:(1) CWR, CGWR, and CBWR at RCP4.5 climatic scenarios in 2030s (S1); (2) CWR, CGWR, and CBWR at RCP8.5 climatic scenarios in 2030s (S2). CWR, CGWR, and CBWR at current climatic conditions (from 1961 to 2010) are used as baseline. According to the CMIP5 multi-model dataset, the 2030s temperature will go up to 1.2-1.4 ${ }^{\circ} \mathrm{C}$ in NCP under different RCP scenarios. Assuming there is no change in the crop planting system and irrigation conditions in the future, the total CWR was predicted to be 123.43 and $125.93 \mathrm{~km}^{3} \mathrm{a}^{-1}$ for $\mathrm{S} 1$ and $\mathrm{S} 2$ scenarios, respectively (Table 6). Compared with the baseline climatic conditions, the total CWR in 2030s will require approximately $8.75-11.25 \mathrm{~km}^{3} \mathrm{a}^{-1}$ additional water. The increment of water requirement was between 8 and $10 \%$ in 2030s. For different crops, future climate change will cause additional water requirements of $4.31-5.20 \mathrm{~km}^{3} \mathrm{a}^{-1}$ for winter wheat, $2.43-3.56 \mathrm{~km}^{3} \mathrm{a}^{-1}$ for summer maize, $1.24-1.42 \mathrm{~km}^{3} \mathrm{a}^{-1}$ for cotton, $0.10-0.15 \mathrm{~km}^{3} \mathrm{a}^{-1}$ for millet, and $0.67-0.92 \mathrm{~km}^{3} \mathrm{a}^{-1}$ for soybean. Compared with other 
Table 5 Comparison between wheat water requirement estimated by CROPWAT and GEPIC model

\begin{tabular}{lcc}
\hline & $\begin{array}{l}\text { CWR estimated by } \\
\text { CROPWAT }\left(\mathrm{km}^{3} \mathrm{a}^{-1}\right)\end{array}$ & $\begin{array}{c}\text { CWR estimated by } \\
\text { GEPIC }\left(\mathrm{km}^{3} \mathrm{a}^{-1}\right)\end{array}$ \\
\hline Beijing & 0.69 & 0.50 \\
Tianjin & 0.54 & 0.41 \\
Hebei & 9.99 & 10.75 \\
Shandong & 15.16 & 13.88 \\
Henan & 16.57 & 19.36 \\
Anhui & 6.81 & 10.14 \\
Jiangsu & 7.03 & 8.95 \\
NCP & 56.78 & 63.99 \\
\hline
\end{tabular}

\begin{tabular}{|c|c|c|c|c|c|c|}
\hline Province & Winter wheat & Summer maize & Cotton & Millet & Soybean & $\begin{array}{l}\text { Total CWR } \\
\left(10^{8} \mathrm{~m}^{3} / \mathrm{a}\right)\end{array}$ \\
\hline
\end{tabular}

Table 6 Average CWR for major crops under various scenarios

\begin{tabular}{|c|c|c|c|c|c|c|}
\hline \multicolumn{7}{|c|}{ Baseline: current conditions (between 1961 and 2010) } \\
\hline Beijing & 6.86 & 8.89 & 0.13 & 0.09 & 0.60 & 16.56 \\
\hline Tianjin & 5.44 & 6.03 & 0.66 & 0.11 & 2.18 & 14.42 \\
\hline Hebei & 99.94 & 97.98 & 20.45 & 10.96 & 23.82 & 253.16 \\
\hline Shandong & 151.56 & 108.28 & 24.02 & 2.12 & 18.07 & 304.06 \\
\hline Henan & 165.67 & 76.17 & 45.14 & 2.64 & 22.59 & 312.21 \\
\hline Anhui & 68.09 & 19.85 & 18.58 & 0.04 & 17.74 & 124.29 \\
\hline Jiangsu & 70.25 & 17.53 & 21.76 & 0.00 & 12.54 & 122.08 \\
\hline NCP & 567.82 & 334.72 & 130.74 & 15.97 & 97.54 & 1146.78 \\
\hline \multicolumn{7}{|c|}{ S1: RCP4.5 scenario(between 2031 and 2040) } \\
\hline Beijing & 6.87 & 8.96 & 0.13 & 0.09 & 0.61 & 16.66 \\
\hline Tianjin & 5.72 & 6.63 & 0.73 & 0.13 & 2.40 & 15.60 \\
\hline Hebei & 103.28 & 100.41 & 21.36 & 11.46 & 24.36 & 260.86 \\
\hline Shandong & 169.96 & 120.88 & 27.52 & 2.39 & 19.95 & 340.71 \\
\hline Henan & 172.79 & 81.65 & 48.56 & 2.84 & 24.06 & 329.89 \\
\hline Anhui & 74.60 & 21.57 & 20.58 & 0.04 & 19.15 & 135.93 \\
\hline Jiangsu & 77.71 & 18.94 & 24.30 & 0.00 & 13.71 & 134.66 \\
\hline $\mathrm{NCP}$ & 610.93 & 359.03 & 143.17 & 16.95 & 104.23 & 1234.31 \\
\hline \multicolumn{7}{|c|}{ S2: RCP8.5 scenario(between 2031 and 2040) } \\
\hline Beijing & 6.91 & 9.46 & 0.14 & 0.09 & 0.64 & 17.23 \\
\hline Tianjin & 5.79 & 6.97 & 0.75 & 0.13 & 2.51 & 16.15 \\
\hline Hebei & 104.20 & 105.14 & 21.94 & 11.87 & 25.40 & 268.54 \\
\hline Shandong & 172.67 & 124.05 & 27.99 & 2.46 & 20.50 & 347.67 \\
\hline Henan & 175.94 & 83.66 & 49.04 & 2.89 & 24.57 & 336.10 \\
\hline Anhui & 75.57 & 21.83 & 20.67 & 0.04 & 19.33 & 137.43 \\
\hline Jiangsu & 78.70 & 19.21 & 24.38 & 0.00 & 13.85 & 136.13 \\
\hline $\mathrm{NCP}$ & 619.77 & 370.31 & 144.90 & 17.48 & 106.78 & 1259.25 \\
\hline
\end{tabular}

results, Liu and Lin (2004) presented that the temperature increase of about $1-4{ }^{\circ} \mathrm{C}$ will cause an additional water requirement of $1.47-19.1 \mathrm{~km}^{3} \mathrm{a}^{-1}$ for winter wheat, $0.59-6.86 \mathrm{~km}^{3} \mathrm{a}^{-1}$ for summer maize, and $0.14-1.65 \mathrm{~km}^{3}$ $\mathrm{a}^{-1}$ for cotton. We find that our results for main crops in general fall in the range of those from Liu and Lin. Both the studies indicate that climate change will have great impact on CWR of winter wheat, followed by summer maize and cotton, and the least impact on soybean and millet. It also shows that winter wheat is the most sensitive crop to climate change.

To better understand the implications of different climatic factors on CWR, this study analyzed the contribution of different temperatures and rainfall conditions in 2030s to CWR increase. Take RCP4.5 climatic scenario as example, four conditions are depicted as follows: C1: Current 
Table 7 Comparison of CWR, CGWR, and CBWR under C1 and C2 conditions (Unit: $10^{8} \mathrm{~m}^{3} / \mathrm{a}$ )

\begin{tabular}{|c|c|c|c|c|c|c|c|c|c|}
\hline & \multicolumn{3}{|c|}{$\mathrm{C} 1$ condition } & \multicolumn{3}{|c|}{$\mathrm{C} 2$ condition } & \multicolumn{3}{|l|}{$\mathrm{C} 2-\mathrm{C} 1$} \\
\hline & CWR & CGWR & CBWR & CWR & CGWR & CBWR & $\Delta \mathrm{CWR}$ & $\Delta \mathrm{CGWR}$ & $\Delta \mathrm{CBWR}$ \\
\hline Winter wheat & 567.82 & 334.39 & 233.43 & 610.12 & 334.39 & 275.73 & 42.3 & 0 & 42.3 \\
\hline Summer maize & 334.72 & 295.96 & 38.76 & 358.84 & 311.93 & 46.91 & 24.12 & 15.97 & 8.15 \\
\hline Cotton & 130.74 & 100.86 & 29.87 & 143 & 100.86 & 42.13 & 12.26 & 0 & 12.26 \\
\hline Millet & 15.97 & 14.16 & 1.81 & 16.87 & 15.06 & 1.81 & 0.9 & 0.9 & 0 \\
\hline Soybean & 97.54 & 82.7 & 14.84 & 103.78 & 83.44 & 20.35 & 6.24 & 0.74 & 5.51 \\
\hline Total & 1146.78 & 828.07 & 318.72 & 1232.61 & 845.68 & 386.93 & 85.83 & 17.61 & 68.21 \\
\hline
\end{tabular}

temperature and rainfall; C2: 2030s temperature and current rainfall; C3: Current temperature and 2030s rainfall; C4: 2030s temperature and 2030s rainfall. Total CWR was predicted to be $114.68,123.26,114.79$, and $123.43 \mathrm{~km}^{3}$ $\mathrm{a}^{-1}$ for $\mathrm{C} 1$ to $\mathrm{C} 4$ conditions, respectively. The results show that the CWR in $\mathrm{C} 2$ will require approximately $8.58 \mathrm{~km}^{3}$ $\mathrm{a}^{-1}$ additional water than $\mathrm{C} 1$. The CWR in C3 was almost similar to $\mathrm{C} 1$, which indicates that $\mathrm{CWR}$ is more sensitive to temperature than rainfall.

Further comparison details on CWR, CGWR, and CBWR changes under $C 1$ and $C 2$ conditions are shown in Table 7. In C2 condition, total CWR, CGWR, and CBWR increments in 2030s were 8.58, 1.76 and $6.82 \mathrm{~km}^{3} \mathrm{a}^{-1}$, respectively. Almost $80 \%$ of the CWR increment is from the CBWR. Especially for the irrigation crops, such as wheat, cotton, and soybean, due to the rise in temperature, CWR increments in C2 were 4.23, 1.26, and $0.62 \mathrm{~km}^{3} \mathrm{a}^{-1}$, respectively. Effective rainfall is far short from meeting the crop growth demands. The CWR increments were almost all derived from irrigation. There is no doubt that the agricultural water shortage crisis will further aggravate under future climate change in NCP regions.

\section{Summary and conclusion}

An accurate estimate of regional CWR with high spatial resolution and analysis of their responses to climate change are of great significance in planning the agricultural water resource management. By applying the CROPWAT model, this study investigated the current CWR, CGWR, and CBWR with a spatial resolution of 5 arc-minute for main crops in the NCP regions. Also, the possible impacts of future climate changes under RCP scenarios on CWR, CGWR, and CBWR were also investigated.

Mean annual total CWR of main crops in crop growing periods amounted to $114.68 \mathrm{~km}^{3} \mathrm{a}^{-1}$ during 1961-2010. The spatial distribution of CWR is closely related to the planting areas and irrigation availability. Highest $C W R$ is found in Henan, Shandong, and Hebei provinces where the proportions were all above $22 \%$. For different crops, the large water consumers are winter wheat and summer maize, CWR proportions of which account for four fifths of the total CWR. Also, it is found that more than $72 \%$ of CWR in NCP comprised green water. Summer maize, millet, and soybean have the high green water proportion with values of $88.42,88.66$, and $84.78 \%$ respectively, while winter wheat has the lowest green water proportion with value of $58.89 \%$ and its production heavily relies on irrigation.

The impacts of climate change on CWR, CGWR, and CBWR were investigated. The results suggest that CWR will significantly increase in 2030s under future RCP climate scenarios. Compared with the current climatic conditions, assuming there is no change in the crop planting system and irrigation conditions in the future, the total CWR in 2030s will require approximately $8.75-11.25 \mathrm{~km}^{3}$ $\mathrm{a}^{-1}$ additional water. It is found that climate change will have great impact on CWR of winter wheat, followed by summer maize and cotton, and the least impact on soybean and millet.

To better understand the implications of different climatic factors on CWR, the contribution of temperature and rainfall to CWR was analyzed. The results show that CWR will require approximately $8.58 \mathrm{~km}^{3} \mathrm{a}^{-1}$ additional water under 2030s temperature and current rainfall condition, while $C W R$ has no change under current temperature and 2030s rainfall. It indicates that CWR increase in 2030s is mainly due to the increase in temperature. Also, under 2030s temperature and current rainfall condition, total CWR, CGWR, and CBWR increments were 8.58, 1.76, and $6.82 \mathrm{~km}^{3} \mathrm{a}^{-1}$, respectively. Almost $80 \%$ of the CWR increment is from the increase of CBWR. It is undoubtedly that irrigation water use pressure will further aggravate under future climate change in NCP.

Acknowledgments We acknowledge the National Climate Center for providing the data of their simulations by regional climate model. This work was supported by the National Natural Science Foundation of China (51279140) and Special Funds for "Tai Shan Scholar" Construction. 


\section{References}

Allen RG, Pereira LS, Raes D, Smith M (1998) Crop evapotranspiration-guidelines for computing crop water requirements. FAO Irrigation and drainage paper 56. FAO, Rome

Antonellini M, Dentinho T, Khattabi A, Masson E, Mollema PN, Silva V, Silveira P (2014) An integrated methodology to assess future water resources under land use and climate change: an application to the Tahadart drainage basin (Morocco). Environ Earth Sci 71(4):1839-1853

Chen YM, Guo GS (1993) A contour map book of main crops water requirement in China. Beijing: China Agriculture Science Press. ISBN: 7800264041/9787800264047

Chen C, Wang EL, Yu Q (2010) Modelling the effects of climate variability and water management on crop water productivity and water balance in the North China Plain. Agric Water Manage 97(8):1175-1184

Chen C, Hagemann S, Liu J (2014) Assessment of impact of climate change on the blue and green water resources in large river basins in China. Environ Earth Sci. doi:10.1007/s12665-0143782-8

Chowdhury S, Al-Zahrani M, Abbas A (2013) Implications of climate change on crop water requirements in arid region: an example of Al-Jouf, Saudi Arabia. J King Saud Univ Eng Sci. 10.1016/j. jksues.2013.11.001

Conrad C, Rahmann M, Machwitz M, Stulina G, Paeth H, Dech S (2013) Satellite based calculation of spatially distributed crop water requirements for cotton and wheat cultivation in Fergana Valley, Uzbekistan. Global Planet Change 110:88-98

Ding YH, Ren GY, Shi GY, Gong P, Zheng XH, Zhai PM, Zhang DE, Zhao ZC, Wang ZW, Wang HJ, Luo Y, Chen DL, Gao XJ, Dai XS (2006) National assessment report of climate change (I): climate change in China and its future trend. Adv Clim Change Res 2:3-8. doi:10.3969/j.issn.1673-1719.2006.01.001 (in Chinese)

Duan AW (2004) Irrigation water quota of main crops in the northern areas. Beijing: China Agriculture Science Press. ISBN: 7801676815/9787801676818

Fader M, Gerten D, Thammer M, Heinke J, Lotze-Campen H, Lucht W, Cramer W (2011) Internal and external green-blue agricultural water footprints of nations, and related water and land savings through trade. Hydrol Earth Syst Sci 15:1641-1660

Falkenmark M (2003) Freshwater as shared between society and ecosystems: From divided approaches to integrated challenges. Philos Trans R Soc Lond B Biol Sci 358(1440):2037-2049

Fan L, Lu CH, Yang B, Chen Z (2012) Long-term trends of precipitation in the North China Plain. J Geogr Sci 22(6):989-1001

FAO (2009) CROPWAT 8.0 Software: A Computer Program for Irrigation Planning and Management. Land and Water Division of FAO; Available at: http://www.fao.org/nr/water/infores_ databases_cropwat.html

George BA, Shende SA, Raghuwanshi NS (2000) Development and testing of an irrigation scheduling model. Agric Water Manage 46(2):121-136

Guo RP, Lin ZH, Mo XG, Yang CL (2010) Responses of crop yield and water use efficiency to climate change in the North China Plain. Agric Water Manage 97(8):1185-1194

Hoff H, Falkenmark M, Gerten D, Gordon L, Karlberg L, Rocksstroem J (2010) Greening the global water system. J Hydrol $384: 177-186$

IPCC (Intergovernmental Panel on Climate Change) (2013) Climate Change 2013: The Physical Science Basis [M/OL]. Cambridge University Press, Cambridge

Iqbal MA, Shen YJ, Stricevic R, Pei HW, Sun HY, Amiri E, Penas A, Rio SD (2014) Evaluation of the FAO AquaCrop model for winter wheat on the North China Plain under deficit irrigation from field experiment to regional yield simulation. Agric Water Manage 135:61-72

Li KN, Yang XG, Liu ZJ, Zhang TY, Lu S, Liu Y (2014) Low yield gap of winter wheat in the North China Plain. Eur J Agron 59:1-12

Liu XY, Lin ED (2004) Impact of climate change on water requirement of main crops in North China. SHUILI XUEBAO 2:77-87 (in Chinese)

Liu J, Savenije HHG (2008) Food consumption patterns and their effect on water requirement in China. Hydrol Earth Syst Sci 12:887-898

Liu J, Yang H (2010) Spatially explicit assessment of global consumptive water uses in cropland: Green and blue water. J Hydrol 384:187-197

Liu JG, Wiberg D, Zehnder AJB, Yang H (2007) Modeling the role of irrigation in winter wheat yield, crop water productivity, and production in China. Irrig Sci 26:21-33

Liu J, Zehnder AJB, Yang H (2009) Global consumptive water use for crop production: the importance of green water and virtual water. Water Resour Res 45(5):W05428. 10.1029/2007WR006051

Liu J, Folberth C, Yang H, Röckström J, Abbaspour K, Zehnder AJB (2013) A global and spatially explicit assessment of climate change impacts on crop production and consumptive water use. PLoS One 8(2):e57750. doi:10.1371/journal.pone.0057750

Lu SL, Wu BF, Wei YP, Yan N, Wang H, Guo SY (2015) Quantifying impacts of climate variability and human activities on the hydrological system of the Haihe River Basin, China. Environ Earth Sci 73:1491-1503. doi:10.1007/s12665-0143799-8

Mimi ZA, Jamous SA (2010) Climate change and agricultural water demand: impacts and adaptations. Afr J Environ Sci Technol 4(4):183-191

Mo X, Liu S, Lin Z, Xu Y, Xiang Y, Mc Vicar TR (2005) Prediction of crop yield, water consumption and water use efficiency with a SVAT-crop growth model using remotely sensed data on the North China Plain. Ecol Model 183:301-322

Mo XG, Liu SX, Lin ZH, Guo RP (2009) Regional crop yield, water consumption and water use efficiency and their responses to climate change in the North China Plain. Agr Ecosyst Environ 134:67-78

Mo XG, Guo RP, Liu SX, Lin ZH, Hu S (2013) Impacts of climate change on crop evapotranspiration with ensemble GCM projections in the North China Plain. Clim Change 120:299-312

Monfreda C, Ramankutty N, Foley JA (2008) Farming the planet: 2. Geographic distribution of crop areas, yields, physiological types, and net primary production in the year 2000. Global Biogeochem Cy 22, GB1022, doi:10.1029/2007GB002947

Moss RH, Edmonds JA, Hibbard KA (2010) The next generation of scenarios for climate change research and assessment. Nature 463:747-756

Nazeer M (2009) Simulation of maize crop under irrigated and rainfed conditions with CROPWAT model. ARPN J Agric Biol Sci 4(2):68-73

Oki T, Kanae S (2006) Global hydrological cycles and world water resources. Science 313(5790):1068-1072

Piao SL, Ciais P, Huang Y, Shen ZH, Peng SS, Li JS, Zhou LP, Liu HY, Ma YC, Ding YH, Friedlingstein P, Liu CZ, Tan K, Yu YQ, Zhang TY, Fang JY (2010) The impacts of climate change on water resources and agriculture in China. Nature 467(7311):43-51

Prăvălie R, Šrodoev I, Patriche CV, Bandoc G, Peptenatu D (2014) The analysis of the relationship between climatic water deficit and corn agricultural productivity in the dobroger plateau. Carpathian Journal of Earth and Environmental Sciences 9(4):201-214 
Qin DH, Stocker T, 259 Authors and TSU (Bern \& Beijing). 2014. Highlights of the IPCC Working Group I Fifth Assessment Report. Adv Clim Change Res 10(1): 1-6. doi:10.3969/j.issn. 1673-1719.2014.01.001(in Chinese)

Rost S, Gerten D, Bondeau A, Lucht W, Rohwer J, Schaphoff S (2008) Agricultural green and blue water consumption and its influence on the global water system. Water Resour Res 44:W09405. doi:10.1029/2007WR006331

Samper J, Li Y, Pisani B (2015) An evaluation of climate change impacts on groundwater flow in the Plana de La Galera and Tortosa alluvial aquifers (Spain). Environ Earth Sci 73:2595-2608. doi:10.1007/s12665-014-3734-3

Shi YL (2008) Study on Reasonable Allocation of Agricultural Resource and Improvement of the Comprehensive Productivity. China Agricultural Press, BeiJing. ISBN 9787109126169

Siebert S, Döll P, Feick S, Hoogeveen J, and Frenken K (2007) Global Map of Irrigation Areas version 4.0.1. Johann Wolfgang Goethe University, Frankfurt am Main, Germany/Food and Agriculture Organization of the United Nations, Rome

Stancalie G, Marica A, Toulios L (2010) Using earth observation data and CROPWAT model to estimate the actual crop evapotranspiration. Phys Chem Earth 35(1-2):25-30

Thevs N, Ovezmuradov K, Zanjani LV, Zerbe S (2015) Water consumption of agriculture and natural ecosystems at the Amu Darya in Lebap Province, Turkmenistan. Environ Earth Sci 73:731-741

Thomson AM, Izaurralde RC, Rosenberg NJ, He X (2006) Climate change impacts on agriculture and soil carbon sequestration potential in the Huang-Hai Plain of China. Agr Ecosyst Environ 114(2-4): 195

Todorovic M (2005) Crop Water Requirements. Water Encycl 3:557-558. doi:10.1002/047147844X.aw59

Wang WJ, Feng H (2012) Water requirement and irrigation systems of winter wheat: CROPWAT-DSSAT model solution in Guanzhong District, Chinese. J Eco-Agric 20(6):795-802

Wang HX, Zhang L, Dawas WR, Liu CM (2001) Improving water use efficiency of irrigated crops in the North China Plain-measurements and modeling. Agric Water Manage 48(2):151-167

Wang J, Wang EL, Feng LP, Yin H, Yu WD (2013) Phenological trends of winter wheat in response to varietal and temperature changes in the North China Plain. Field Crops Res 144:135-144
Xia J, Qiu B, Li YY (2012) Water resources vulnerability and adaptive management in the Huang, Huai and Hai river basins of China. Water Int 37:523-536

Xiao DP, Tao FL (2014) Contributions of cultivars, management and climate change to winter wheat yield in the North China Plain in the past three decades. Eur J Agron 52:112-122

Yao WY, Xu JX (2013) Impact of human activity and climate change on suspended sediment load: the upper Yellow River, China. Environ Earth Sci 70:1389-1403. doi:10.1007/s12665-0132223-4

Zang C, Liu J, van der Velde M, Fraxner F (2012) Assessment of spatial and temporal patterns of green and blue water flows under natural conditions in inland river basins in northwest China. Hydrol Earth Syst Sci 16(8):2859-2870

Zang C, Liu J, Jiang L, Gerten D (2013) Impacts of human activities and climate variability on green and blue water flows in the Heihe river basin in Northwest China. Hydrol Earth Syst Sci Discuss 10:9477-9504

Zhang H, Wang X, You M, Liu C (1999) Water-yield relations and water-use efficiency of winter wheat in the North China Plain. Irrig Sci 19:37-45

Zhang GH, Lian YL, Liu CH, Yan MJ, Wang JZ (2011) Situation and Origin of Water Resources in Short Supply in North China Plain. J Earth Sci Environ 33(2):172-176 (in Chinese)

Zhang WB, Zha XC, Li JX, Liang W, Ma YG, Fan DM, Li S (2014) Spatiotemporal Change of Blue Water and Green Water Resources in the Headwater of Yellow River Basin, China. Water Resour Manage 28:4715-4732

Zhao XN, Hu KL, Stahr K (2013) Simulation of SOC content and storage under different irrigation, fertilization and tillage conditions using EPIC model in the North China Plain. Soil Tillage Res 130:128-135

Zhou H, Zhang X, Xu H, Ling H, Yu P (2012) Influence of climate change and human activities on Tarim River runoffs in China over the past half century. Environ Earth Sci 67(1):231-241

Zinyengere N, Crespo O, Hachigonta S, Tadross M (2014) Local impacts of climate change and agronomic practices on dry land crops in Southern Africa. Agr Ecosyst Environ 197:1-10 